\title{
Usuwanie odkształceń spawalniczych
}

\section{Elimination of welding distortions}

\section{Streszczenie}

Tematem artykułu jest prostowanie na zimno i na gorąco elementów spawanych. Przedstawiono rozkład naprężeń przy prostowaniu na zimno, a także założenia technologiczne do prostowania metodą miejscowego nagrzania elementów długich, przekrojów złożonych i płaszczyzn wybrzuszonych. Omówiono wpływ materiału, źródła ciepła i temperatury miejscowego nagrzewania na proces usuwania odkształceń. Zaprezentowano technikę prostowania przez miejscowe nagrzanie oraz rodzaje stref nagrzewania. Zamieszczono praktyczne przykłady prostowania płomieniowego elementów spawanych.

\section{Abstract}

There was the straightening of welded elements shown (both with and without pre-heating). The stress distribution at cold straightening was presented. There were technological assumptions for straightening by means of local heating of long elements described. The authors presented the influence of material, heat source and the temperature of local heating on the process of distortion removal. The techniques of straightening by local heating and the types of heat zones were described. Examples of flame straightening of welded elements were given.

\section{Wstęp}

Nawet przy bardzo starannej analizie rodzaju i wielkości odkształceń, wywołanych skurczem spawalniczym, i zastosowaniu odpowiednich środków zaradczych, mogą powstać zmiany kształtu i wymiarów elementów, które utrudniają lub uniemożliwiają zestawienie ich w większy zespół, czy też w całość. Zachodzi zatem często konieczność usuwania skutków skurczu przez prostowanie [1]. Prostowanie elementów lub części odkształconych podczas spawania albo przed spawaniem wykonuje się bądź na zimno - mechanicznie, lub przez miejscowe podgrzewanie. Ponieważ w obydwu wypadkach w prostowanym elemencie powstają duże naprężenia i odkształcenia plastyczne, zabiegi takie wywierają pewien wpływ na właściwości wytrzymałościowe materiału. Przy prostowaniu długich elementów najczęściej chodzi o usunięcie krzywizny w jednej lub dwóch płaszczyznach wzajemnie prostopadłych, rzadziej - o wyprostowanie elementów skręconych śrubowo. W elementach płaskich o dużych wymiarach płaszczyzn dąży się do wyprostowania wybrzuszeń i miejscowych wypukłości [2].

Dr hab. inż. Jacek Słania, prof. IS- Politechnika Częstochowska.

\section{Prostowanie na zimno}

Prostowanie na zimno polega na stosowaniu takiego obciążenia elementu siłami zewnętrznymi zginającymi, które wywołają w materiale odkształcenia trwałe. W ten sposób prostuje się zazwyczaj długie elementy o małym momencie bezwładności i małym przekroju poprzecznym. Aby powstały odkształcenia trwałe, w przekroju muszą działać naprężenia na granicy plastyczności. Na skutek odkształceń plastycznych na zimno w materiale zmieniają się właściwości plastyczne, co dla materiałów o podwyższonej wytrzymałości, a małym wydłużeniu, jest zjawiskiem niekorzystnym. W elementach spawanych warunki są jeszcze gorsze, gdyż najczęściej siły zewnętrzne przy prostowaniu muszą wywołać naprężenia
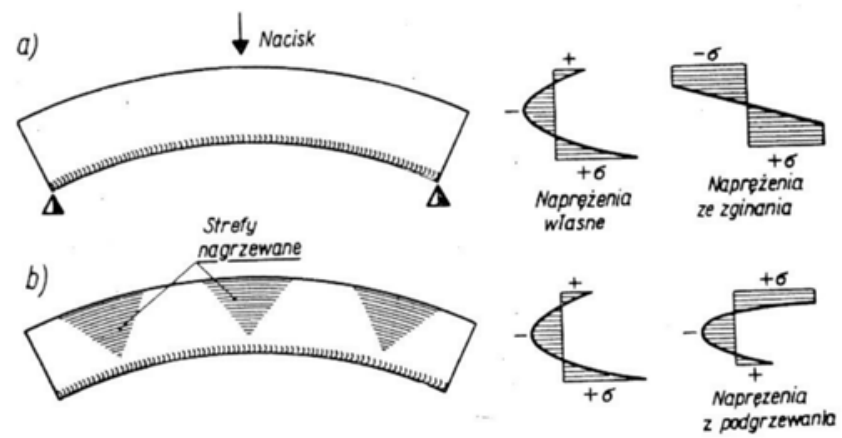

Rys. 1. Schemat naprężeń przy prostowaniu: a) na zimno, b) z podgrzewaniem miejscowym [2]

Fig.1. Distortion scheme at: a) cold straightening, b) local heating [2] 
wewnętrzne tego samego znaku, co istniejące w elemencie naprężenia ze skurczu strefy spawania. Wskutek tego prostowanie na zimno czasem może spowodować znaczne zmiany właściwości plastycznych materiału, co pogarsza spawanie, gdy prostowanie będzie wykonywane przed procesem. Podczas prostowaniu elementów spawanych w strefie spawania mogą powstać pęknięcia (rys. 1).

Z tych względów odkształcenia plastyczne przy prostowaniu na zimno nie powinny przekraczać wydłużeń odpowiadających granicy plastyczności materiału, tj. $2 \%$. Ponieważ w materiale nie powinny być całkowicie wyczerpane właściwości plastyczne, należy ograniczyć wielkość wydłużeń trwałych do 1\%. Wychodząc z tych założeń, można ustalić dopuszczalne wielkości krzywizn, jakie mogą być prostowane na zimno.

Przy spawaniu wiotkich prętów nastąpi ich skrzywienie w przybliżeniu po łuku koła o promieniu $r$ (rys. 2). Długość łuku po stronie rozciąganej $L_{1}$ można obliczyć na podstawie przyjętego wydłużenia plastycznego i przy założeniu płaskich przekrojów, ze wzoru

$$
L_{1}=L+0,01 L=(1+0,01) L
$$

Najmniejszy promień krzywizny oblicza się z zależności geometrycznych:

$$
\begin{gathered}
\frac{r}{r+e_{1}}=\frac{L}{L_{1}}=\frac{L}{(1+0,01) L} \\
r+0,01 r=r+e_{1} \\
\text { dla } e_{1}=e_{2} \quad r=\frac{h}{0,02}=50 h .
\end{gathered}
$$

Przy odkształceniach elementu, których promień jest mniejszy od $100 \mathrm{e}_{1}$ lub $50 \mathrm{~h}$, prostowanie musi być wykonywane na gorąco. Na gorąco powinny być również prostowane elementy załamane lub mające miejscowe zakrzywienia o bardzo małych promieniach.

Jeszcze gorsze skutki wywołuje prostowanie na zimno uderzeniami, przy których następuje miejscowy zgniot materiału. $W$ tym przypadku zachodzą bowiem miejscowe zmiany strukturalne, pogarszające właściwości

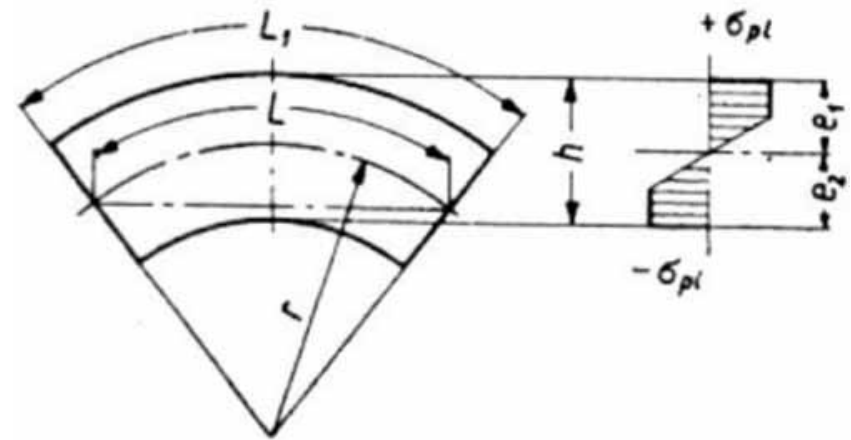

Rys. 2. Odkształcenia plastyczne przy prostowaniu na zimno [2] Fig. 2. Plastic distortion at cold straightening [2] mechaniczne materiału. W przekroju o większym momencie bezwładności i większej sztywności powinny być przyłożone bardzo duże siły, aby element naprostować. Prostowanie na zimno wybrzuszeń w blachach jest trudne ze względu na sprężynowanie większej płaszczyzny. Dlatego prostowanie za pomocą miejscowego nagrzewania, które jest znacznie łatwiejsze do przeprowadzenia, ma duże zastosowanie [2].

\section{Prostowanie metodą miejscowego nagrzewania}

Technicznie najprostszym i najbardziej racjonalnym sposobem prostowania jest lokalne nagrzewanie za pomocą palnika acetylenowo-tlenowego. Skuteczność oraz nieszkodliwość tej metody dla prostowanego elementu zależy od pewnych podstawowych reguł, omówionych niżej. Podgrzewanie stosuje się również przy prostowaniu odkształconej konstrukcji [1].

Prostowanie pewnych określonych miejsc odkształconego elementu za pomoca podgrzewania polega również na wywoływaniu trwałych odkształceń. W wyniku ogrzewania miejscowego materiału, w warunkach ograniczonej możliwości wydłużenia strefy przyległej, powstają w tych miejscach naprężenia ściskające i plastyczne skrócenia materiału. Po ostygnięciu nagrzanych miejsc tworzą się naprężenia wewnętrzne rozciągające, które powodują odkształcenia elementu, podobnie jak naprężenia własne przy spawaniu. W porównaniu do prostowania na zimno odkształcenia plastyczne przy prostowaniu za pomocą podgrzewania powstają wówczas, gdy materiał ma wysoką temperaturę. Odkształcenia trwałe powstają więc w strefie nagrzania na skutek sztywności elementu i bardzo dużej plastyczności materiału nagrzanego $w$ tej temperaturze. Gdy temperatura nagrzania nie przekracza $720^{\circ} \mathrm{C}$, w miejscu nagrzania nie występuja zmiany strukturalne, $w$ przeciwieństwie do prostowania na zimno. Po ostygnięciu w elemencie spawanym pozostają naprężenia o znaku przeciwnym do znaku naprężeń własnych ze spawania. Jednak na skutek dodatkowego nagrzewania wprowadza się do elementu prostowanego dodatkowe naprężenia własne, których ujemne skutki są takie same, jak naprężeń powstających przy spawaniu. Przy nagrzewaniu należy więc dążyć do warunków sprzyjających tworzeniu się odkształceń w tej strefie. Nagrzewać należy na większej szerokości ze stopniowym rozkładem temperatury. W żadnym wypadku nie należy sztucznie (np. wodą) przyspieszać studzenie miejsc ogrzanych.

Elementy prostowane podgrzewa się przeważnie zwykłymi palnikami gazowymi stosowanymi do spawania lub palnikami ze specjalną końcówką. Niekiedy w celu wyprostowania elementu układa się spoinę łukiem po stronie wypukłej, nagrzewając $w$ ten sposób odpowiednie miejsca na konstrukcji. Prostowanie za pomocą dodatkowych spoin nie jest wskazane, gdyż 

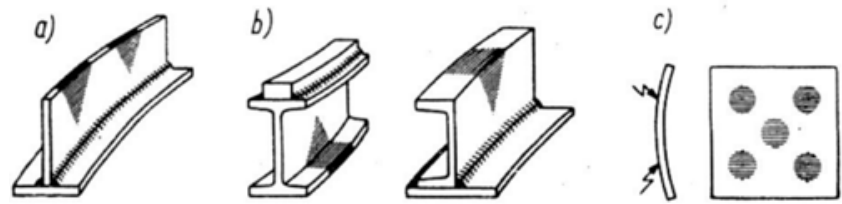

Rys. 3. Prostowanie za pomocą miejscowego nagrzania: a) elementów długich, b) przekrojów złożonych, c) płaszczyzn wybrzuszonych [2] Fig. 3. Straightening by means of local heating: a) of long elements, b) complex intersection heating, c) of bulge plane [2]

podczas procesu następują zawsze zmiany strukturalne w strefie spawania, a naprężenia na osi spoiny osiągają bardzo duże wartości przy silnej koncentracji. Natomiast przy podgrzewaniu gazowym strefa nagrzania jest znacznie szersza, dzięki czemu siłę potrzebną do wyprostowania elementu uzyskuje się przy mniejszych naprężeniach dodatkowych.

Aby wyprostować długie elementy, wygięte łukowo na skutek spawania, podgrzewa się je po stronie wypukłej, w kilku miejscach na płaszczyznach o kształcie trójkąta (rys. 3). Strefa nagrzana powinna sięgać poza środek przekroju. W przekrojach złożonych miejsca nagrzewania należy ustalać w taki sposób, żeby po wyprostowaniu elementu w jednej płaszczyźnie nie nastąpiło wygięcie w drugiej. Przy prostowaniu wybrzuszonych powierzchni blach podgrzewa się wiele punktów równocześnie po stronie wypukłej (rys. 3c). Punkty nie powinny być zbyt małe, żeby nie wywołać dużej koncentracji naprężeń, które w takich wypadkach będą przestrzenne. Również cienkie sfalowane blachy nagrzewa się w wielu punktach, wywołując w nich naprężenia rozciągające [2].

Znacznie trudniejsze jest prostowanie odkształconych konstrukcji przestrzennych, dla których należy przeanalizować sposób wprowadzenia naprężeń dodatkowych, żeby ustalić miejsca podgrzewania. Prostowanie konstrukcji przez podgrzewanie wymaga, również jak przy spawaniu, opracowania technologicznego. W pracach spawalniczych w wielu wypadkach jest konieczne ustalenie temperatury przedmiotu - np. przy wyżarzaniu miejscowym, przy podgrzewaniu lub prostowaniu. Najpewniejszym środkiem jest oczywiście pomiar temperatury za pomocą termometrów lub termoelementów.

\section{Istota procesu}

Każdy proces prostowania wymaga albo wydłużenia miejsca, które jest za krótkie, albo skrócenia miejsca, które jest za długie w prostowanym elemencie. Przez skracanie lub wydłużanie trzeba doprowadzić materiał lokalnie do płynięcia, czyli do przekroczenia jego granicy plastyczności. Przy prostowaniu przez nagrzewanie płomieniem stosuje się skurcz, który po nagrzaniu miejsca zbyt wydłużonego ma spowodować jego skrócenie [1].

\section{Temperatura miejsca nagrzanego}

Miejsce nagrzewane powinno osiągnąć temperaturę, przy której metal jest całkowicie plastyczny, tzn. dość miękki, aby naprężenia ściskające, wywołane rozszerzaniem się w miejscu nagrzewania, zanikły i nie działały na otaczający chłodny metal. W tym celu należy osiągnąć temperaturę wiśniowego żaru (rzędu $900^{\circ} \mathrm{C}$ ), nie więcej jednak niż $1000^{\circ} \mathrm{C}$ (żar pomarańczowy) z uwagi na niebezpieczeństwo rozrostu ziarna. Nagrzewać należy szybko, tak aby jak najprędzej uplastycznić miejsca nagrzewane i ograniczyć do minimum odpływ ciepła do metalu sąsiadującego, który powinien pozostawać chłodny i w ten sposób przeciwstawiać się rozszerzaniu [1].

\section{Wpływ materiału}

Bez żadnych ograniczeń można prostować elementy ze stali niskowęglowej, mającej duże wydłużenie, ale zastosowanie tego zabiegu na elementach ze stali stopowych wymaga ostrożności, Trzeba dobrze analizować powstałe już odkształcenia, zanim podejmie się decyzję o prostowaniu. Stan dostawy stali wpływa na skuteczność zabiegu w ten sposób, że stal normalizowana poddaje się skurczowi w nieco mniejszym stopniu niż stal w stanie surowym (tj. bezpośrednio po walcowaniu) [1].

\section{Źródło ciepła}

Najbardziej przydatnym źródłem ciepła jest palnik acetylenowo-tlenowy, dzięki wysokiej temperaturze płomienia, a zatem i dużej prędkości nagrzewania. Do prostowania blach cienkich (do $3 \mathrm{~mm}$ ) należy dobierać wydajność palnika tak samo jak do spawania, tj. średnio $100 \mathrm{l} / \mathrm{h}$ acetylenu na $1 \mathrm{~mm}$ grubości. Dla blach grubszych wydajność powinna być $2 \div 3$ razy większa w stosunku do wydajności, jaką wybrałoby się do spawania blach danej grubości. Na przykład dla grubości $10 \mathrm{~mm}$ przewiduje się do spawania wydajność palnika rzędu $1000 \mathrm{l} / \mathrm{h}$, czyli do prostowania blachtej grubości należałoby użyć nasadki o wydajności ok. $2000 \div 3000 \mathrm{l} / \mathrm{h}$. Palnik przeznaczony do podgrzewania złączy przy spawaniu ma wydajność $1600 \div 4000 \mathrm{l} / \mathrm{h}$, nadaje się zatem również do prostowania przez nagrzewanie dla blach średniej grubości (do ok. $20 \mathrm{~mm}$ ) [1].

\section{Technika prostowania przez nagrzewanie}

Zabieg jest prosty, lecz wymaga uwagi i metodyczności w postępowaniu:

- należy starannie wyznaczyć odkształcenia, które zamierza się usunąć, stosując napięty drut, liniały itp. do wytrasowania granic odkształceń na elemencie i ustalenia ważności, 
- każda strefa musi znajdować się tylko w obszarze odkształconym i nie wolno powtarzać nagrzewania w tym samym miejscu; gdyby np. okazało się, że potrzebne są dodatkowe strefy, należy je wybrać w miejscach sąsiadujących z poprzednimi strefami,

- kształt stref nagrzewania (opisanych niżej) powinien odpowiadać spodziewanemu efektowi,

- liczba stref nagrzewania zależy od wielkości odkształcenia, ustalenie jej wymaga doświadczenia, należy zatem wykonywać zabieg stopniowo, tzn. lepiej jest wprowadzać strefy dodatkowe, jeżeli początkowy wynik był niewystarczający, niż „przegiąć” element wskutek zastosowania zbyt dużych, czy zbyt licznych stref nagrzewania,

- element nagrzewany powinien mieć swobodę prostowania się, wszelkie zamocowanie może albo hamować efekt skurczu, albo go wzmagać, fałszując przewidywane skutki nagrzewania, należy zatem w razie konieczności uwolnić element z zamocowania, nawet jeśli by to oznaczało wycięcie jakiejś spoiny,

- jeżeli element uległ odkształceniom złożonym i wymaga prostowania w dwu lub więcej płaszczyznach, należy kolejne zabiegi prostowania wykonać oddzielnie dla każdej płaszczyzny,

- skutki nagrzewania należy sprawdzać po całkowitym wystygnięciu elementu [1].

\section{Rodzaje stref nagrzewania}

Strefom nagrzewania nadaje się zwykle kształty geometryczne zestawione na rysunku 4. Wielkość wybranego kształtu zależy od wielkości odkształcenia, w obszarze którego wszystkie strefy muszą się mieścić. Należy przy tym pamiętać o ewentualności dodatkowego nagrzewania, gdyby po pierwszej operacji prostowanie nie było całkowite, strefy nie mogą więc być zbyt duże, ani zbyt gęsto rozmieszczone [1].

\section{Wybór stref nagrzewania}

Strefy nagrzewania wybiera się zależnie od charakteru odkształcenia i od przekroju elementu prostowanego. Zasady wyboru stref nagrzewania dla kształtowników lub belek złożonych o podobnym przekroju, odkształconych w jednej płaszczyźnie, pokazano na rysunku 4 [1].

\section{Sposoby zwiększenia skuteczności zabiegu}

W szczególnych przypadkach można zwiększyć skuteczność zabiegu nagrzewania przez:

- przyspieszone stygnięcie stref nagrzanych za pomocą powietrza sprężonego lub wody, dzięki czemu efekt nagrzewania jest bardziej skupiony - sposób ten znajduje zastosowanie głównie przy prostowaniu większych powłok z cienkich blach (np. pudeł wagonu);
Punkty cieplne (blachę obciążyć)
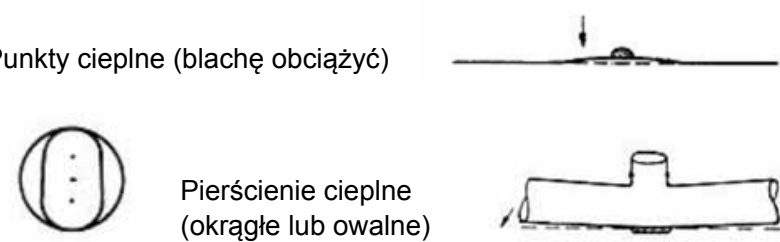

Pierścienie cieplne (okrągłe lub owalne)
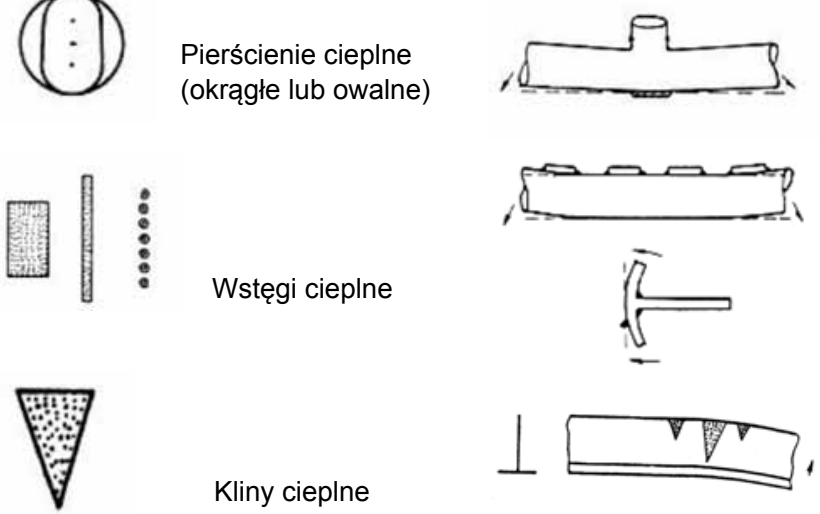

Kliny cieplne

Kombinacje stref nagrzewania.

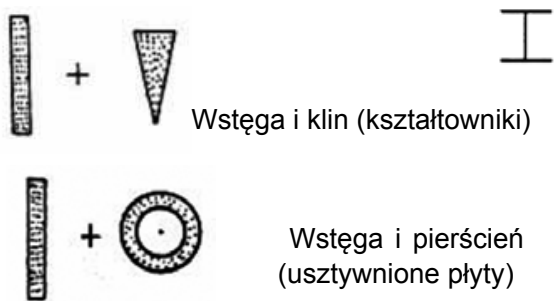

Rys. 4. Kształty stref nagrzewania [1]

Fig. 4. Shapes of heating zones [1]

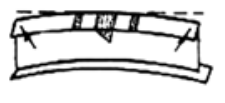

Kątowniki

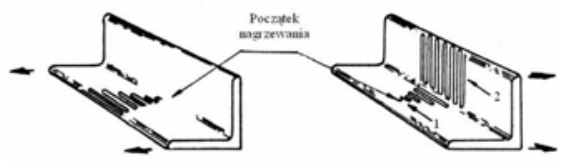

Ceowniki
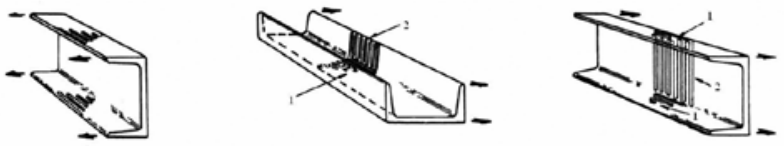

Teowniki
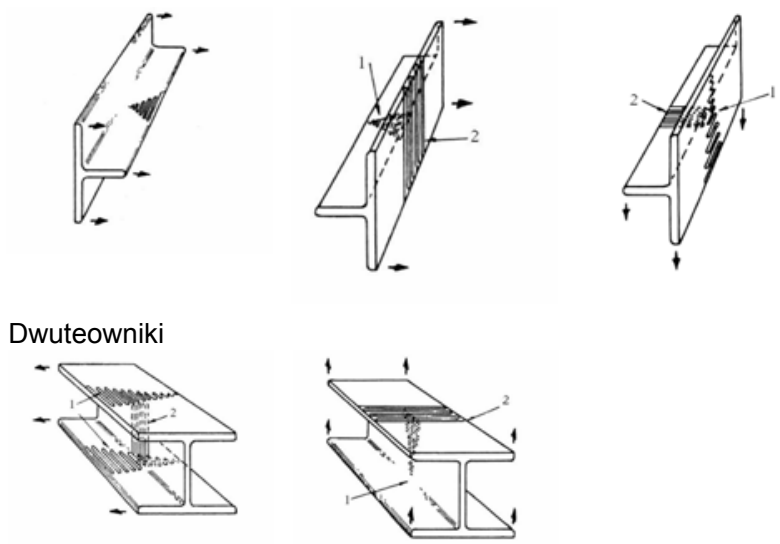

Nagrzewanie elementu w kształcie klina należy rozpoczynać od wierzchołka do odstawy klina. Cyfry oznaczają kolejność nagrzewania. Ta sama cyfra odniesienia do dwu miejsc nagrzewania oznacza, że miejsca te należy nagrzewać jednocześnie. Strzałki oznaczają kierunek, w którym nagrzewany element wyprostuje się pod wpływem nagrzewania.

Rys. 5. Prostowanie kształtowników przez nagrzewanie [1]

Fig. 5. Straightening of sections by heating [1] 


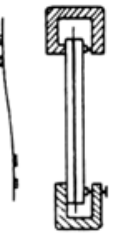

Rys. 6. Prostowanie blach przez nagrzewanie: a) blach cienkich b) blach grubych [1]

Fig. 6. Straightening of sheets by: a) sheet metal heating, b) metal plate heating [1]

- hamowanie rozszerzania się przy podgrzewaniu; jak wiadomo, podczas nagrzewania rozszerzający się metal wywoła początkowo odkształcenie w kierunku odwrotnym do odkształcenia końcowego po ostygnięciu - przeciwstawiając się temu odkształceniu; można wywołać lokalne spęczenie co zwiększy efekt skurczu podczas stygnięcia, sposób ten stosuje się zwykle łącznie ze sposobem prostowania blach cienkich; przez zaciśnięcie ich między dwiema płytami z otworami, przez które odbywa się nagrzewanie palnikami i chłodzenie (rys. 6a), można go też użyć na elementach grubszych przez ich zamocowanie (rys. 6b);

- spęczenie mechaniczne stref nagrzanych (młotkowaniem itp.), które może być użyte wyjątkowo i pod ścisłą kontrolą temperatury zabiegu [1].

\section{Przykłady}

Dwuteownik wysokości 425 mm, długości 10,2 m i masie $1060 \mathrm{~kg} \mathrm{z}$ wycięciem w dwu płaszczyznach.

Wygięcie $30 \mathrm{~mm} \mathrm{z}$ płaszczyzny półki usunięto przez nagrzewanie pięcioma strefami z kombinacji klinowo-wstęgowej, stosując jednocześnie dwa palniki. Nagrzewanie każdej ze stref trwało 4 min, a przebieg prostowania był następujący:

strefa 1 - zmniejszyła wygięcie o $12 \mathrm{~mm}$ (z 30 na $18 \mathrm{~mm}$ ), strefa 2 - zmniejszyła wygięcie o $8 \mathrm{~mm}$ (z 18 na $10 \mathrm{~mm})$, strefa 3 - zmniejszyła wygięcie o $3 \mathrm{~mm}$ (z 10 na $7 \mathrm{~mm}$ ), strefa 4 - zmniejszyła wygięcie o $4 \mathrm{~mm}$ (z 7 na $3 \mathrm{~mm}$ ), strefa 5 - zmniejszyła wygięcie o $3 \mathrm{~mm}$ (z 3 na $0 \mathrm{~mm}$ ).

\section{Podsumowanie}

W artykule przedstawiono podstawy teoretyczne prostowania na zimno i prostowania płomieniowego na gorąco. Omówiono również od strony praktycznej kolejność postępowania przy prostowaniu na gorąco. Przedstawiony sposób postępowania oraz zamieszczone przykłady praktyczne mogą być pomocą przy opracowywaniu technologii prostowania płomieniowego. Należy jednak pamiętać o zweryfikowaniu doświadczalnym przedstawionych zasad postępowania przed ich wprowadzeniem do praktyki.
Wymiary stref wynosiły ok. 250x40 mm. Stygnięcie trwało $2 \mathrm{~h}$.

Wygięcie $20 \mathrm{~mm} \mathrm{z}$ płaszczyzny środnika usunięto przez nagrzewanie 3 strefami klinowo-wstęgowymi, również przy jednoczesnym użyciu dwu palników. Nagrzewanie każdej ze stref o wymiarach $50 \times 70 \mathrm{~mm}$ trwało 2 min, a stygnięcie $1 \mathrm{~h}$.

Dwuteownik szerokopasmowy IP18 długości $3,80 \mathrm{~m}$ z silnym wygięciem $70 \mathrm{~mm}$ z płaszczyzny półki (rys. 8).

Wygięcie usunięto dziewięcioma strefami klinowowstęgowymi o wymiarach $140 \times 40 \mathrm{~mm}$. Dwuteownik był zamocowany i obciążony. Przebieg prostowania był następujący:

strefy 1 i 2 - zmniejszyły wygięcie o $24 \mathrm{~mm}$ (z 70 na $56 \mathrm{~mm}$ ),

strefy 3 i 4 - zmniejszyły wygięcie o $23 \mathrm{~mm}$ (z 56 na $33 \mathrm{~mm}$ ),

strefy 5, 6, 7 - zmniejszyły wygięcie o $24 \mathrm{~mm}$ (z 33 na $9 \mathrm{~mm}$ ),

strefy 8 i 9 -zmniejszyły wygięcie o $9 \mathrm{~mm}$ (z 9 na $0 \mathrm{~mm}$ ).

W obu przypadkach należy zwrócić uwagę na rozmieszczenie i kolejność nagrzewania (pozostawione miejsca między strefami).
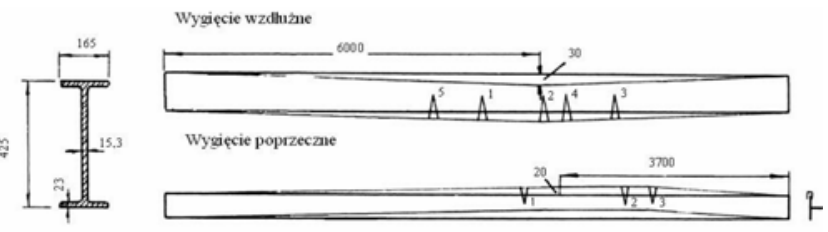

Rys. 7. Prostowanie dwuteownika [1]

Fig. 7. Straightening of I-section [1]

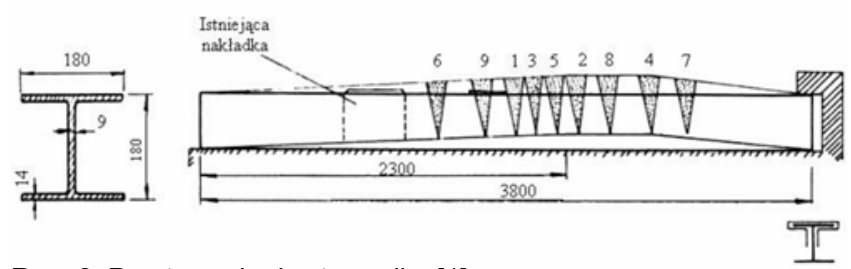

Rys. 8. Prostowanie dwuteownika [1]

Fig. 8. Straightening of I-section [1]

\section{Literatura}

[1] Juffy E.: Odkształcenia spawalnicze. Wytyczne obliczania i usuwania. Biuro Studiów i Projektów Konstrukcji Stalowych MOSTOSTAL, Warszawa 1962.

[2] Śledziewski E.: Technologiczne plany spawania. Podstawy projektowania. PWT, Warszawa 1957. 